\title{
Unearthing the entangled roots of urban agriculture
}

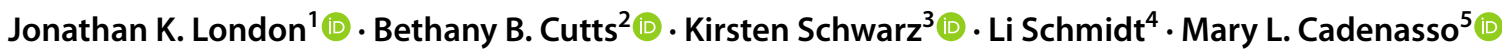

Accepted: 18 September 2020 / Published online: 24 November 2020

(c) The Author(s) 2020

\begin{abstract}
This study examines urban agriculture (UA) in Sacramento, California (USA), the nation's self-branded "Farm-to-Fork Capital," in order to highlight UA's distinct yet entangled roots. The study is based on 24 interviews with a diverse array of UA leaders, conducted as part of a five-year transdisciplinary study of UA in Sacramento. In it, we unearth three primary "taproots" of UA projects, each with its own historical legacies, normative visions, and racial dynamics. In particular, we examine UA projects with "justice taproots," "health taproots," and "market taproots." We use this analysis to understand how different kinds of UA projects are embedded in racial capitalism in ways that transform relationships between people, the city, and food systems. Unearthing these entangled roots helps illuminate UA's underlying politics, showing how these roots grow in both competitive and symbiotic ways within the soil matrix of racial capitalism. We argue that these roots interact differently with racial capitalism, creating disparities in their growth trajectories. In particular, UA projects associated with the justice taproot are historically underrepresented and undervalued. However, we argue that there are some prospects for building alliances between the UA movement's three roots, and that these are both promising and problematic.
\end{abstract}

Keywords Urban agriculture $\cdot$ Racial capitalism $\cdot$ Food justice $\cdot$ Sacramento $\cdot$ California

\section{Abbreviations \\ BHC Building Healthy Communities \\ BLM Black Lives Matter}

Jonathan K. London

jklondon@ucdavis.edu

Bethany B. Cutts

bbcutts@ncsu.edu

Kirsten Schwarz

kschwarz@luskin.ucla.edu

Li Schmidt

lnschmidt@ucdavis.edu

Mary L. Cadenasso

mlcadenasso@ucdavis.edu

1 Department of Human Ecology, UC Davis, One Shields Avenue, 2335 Hart Hall, Davis, CA 95616, USA

2 Department of Parks, Recreation, and Tourism Management, Center for Geospatial Analytics, North Carolina State University, 2800 Faucette Drive, Raleigh, NC 27695, USA

3 UCLA Luskin School of Public Affairs, 5363 Public Affairs Building, Los Angeles, CA 90095-1656, USA

4 Agriculture Sustainability Institute/Sustainable Agriculture Research and Education Program, UC Davis, Davis, USA

5 Department of Plant Sciences, UC Davis, One Shields Avenue, Davis, CA 95616, USA
SBF Soil Born Farms

SUAC Sacramento Urban Agriculture Coalition

UA Urban Agriculture

UC Davis University of California, Davis

YFUF Yisrael Family Urban Farm

\section{Introduction}

In cities across the United States and the world, urban agriculture (UA) movements are building sustainable and equitable urban agricultural systems that confront structural factors like structural racism, uneven capital accumulation, and environmental injustice (Alkon and Agyeman 2011; Alkon and Mares 2012; Gottlieb and Joshi 2010). UA movements have been both commended and critiqued because of the ways they resist, transform or reproduce racial inequities observed in conventional food systems and urban development processes (Block et al. 2012; Bradley and Herrera 2016; Cohen and Reynolds 2015; Galt et al. 2014; Reynolds 2015).

A burgeoning field of scholarship on food justice has highlighted efforts by communities of color to promote selfempowerment through culturally resonant food ways, food sovereignty, and community development based on social 
equity. This research aims to develop and apply a framework that critiques and decenters whiteness, and brings racial justice into the core of the UA movement (Alkon and Mares 2012; Anguelovski 2015; Billings and Cabbil 2011; Bradley and Galt 2014; Bradley and Herrera 2016; Dixon 2014; Hoover 2013; McCutcheon 2019; McClintock 2018; Slocum 2006, 2007; Ramirez 2015; Reese 2018; Sbicca and Myers 2017; Slocum 2007; White 2017). Recent work has drawn on theories of racial capitalism (Johnson and Lubin 2017; Pulido and De Lara 2018; Robinson 2000), and analyses of black geographies and plantation futures (McCutcheon 2019; McKittrick 2011, 2013; Ramirez 2015; Reese 2018), which are seen as fertile settings for understanding and pursuing food justice.

This paper takes up this challenge, and explores the relationship of racial capitalism to UA, using a case study of Sacramento, California (USA). In it, we draw from stakeholder interviews, participant observation, and archival document analysis to unearth three distinct, yet intertwined kinds of UA projects, each with its own complex historical legacy, normative vision and placement within the dynamics of racial capitalism. We use the metaphor of the "taproot" to characterize key elements of the UA movement, and the metaphor of the "soil matrix" to refer to the underlying substrate of racial capitalism where these roots grow. Accordingly, a taproot represents the ways that UA projects are organized around a central set of values, ideologies and political commitments. Using the taproot metaphor, we will refer to projects as being either 'justice-rooted,' 'health-rooted,' or 'market-rooted.' The soil matrix represents certain structures and processes of racial capitalism (Johnson and Lubin 2017; Robinson 2000). Each type of taproot interacts in distinct ways with the soil matrix, reproducing, resisting, and/ or transforming the structural conditions in which it grows. The soil matrix, in turn, produces different types of feedback to the different taproots, favoring some, and setting off a struggle to survive for others. The taproots compete with each other for resources, but also work symbiotically for their mutual benefit. Depending on their strategies, UA projects with different taproots can also change the nature of the soil matrix itself.

Within this socio-natural agricultural system, we look at UA projects with justice, health, and market taproots, and ask: what are their historical bases, characteristics, and interrelationships? How does racial capitalism structure the connections and differentiation within and among them? We argue that these entangled roots and their interactions with racial capitalism are important attributes of UA in Sacramento, and that by unearthing them, one can identify critical dynamics between communities, racial justice, and the food system. Conversely, without this root and soil analysis, it will be difficult if not impossible to fully account for the variegated nature of UA. More broadly, this analysis can provide a powerful substrate upon which to grow critical new understandings of the racialized dimensions of UA movements.

\section{Theoretical framework: growing urban agriculture in the soil of racial capitalism}

To decode the variegated landscape of UA, we draw on the overarching framework provided by theories of racial capitalism (Johnson and Lubin 2017; Robinson 2000) to analyze food justice, and its relationship to other elements of the UA movement. The concept of racial capitalism-credited to renowned scholar of Black radical tradition, Cedric Robinson (2000) - bridges two fundamental social critiques: the materialism of Marx, and the myriad, mostly twentiethcentury analyses of racism. In brief, racial capitalism understands that capitalism is racial, and was never not racial; and that racism enabled capitalism's rise to dominance in Europe via a globalized system of chattel slavery and settler colonialism (Melamed 2011; 2015; Robinson 2000).

Grounding one's analysis of UA in racial capitalism can help identify the critical practices that shape the material and discursive nature of the soil matrix in which it grows. The soil matrix of racial capitalism catalyzes, and is dependent on, the production of "empty, lifeless, Blackened spaces ... through capital disinvestment, white flight, gentrification, urban renewal, incarceration, and policing" (Bledsoe and Wright 2019, p. 6). Gilmore (2017, p. 226) evokes "racial capitalism's dramatically scaled cycles of place-making, including all of chattel slavery, imperialism, settler colonialism, resource extraction, infrastructure coordination, urban industrialization, regional development and the financializing of everything." While analyses like these do not address UA per se, they set up critiques of the ways in which UA is bound up in processes of racial capitalism, which in turn produce and reproduce structural inequities.

Countering the depredations of racial capitalism is Gilmore's notion of an "abolition geography" that seeks to "destroy the geography of slavery by mixing their labor with the external world to change the world and thereby themselves" (2017, p. 227). If one element of Gilmore's "external world" is the soil, then abolition offers a way to use UA in liberatory projects to claim sovereignty over bodies, land, and labor (Harris 1993). In a similar way, McKittrick takes plantation geographies, a particular kind of black geography in which the plantation is cast as "the penultimate site of black dispossession, antiblack violence, racial encounter, and innovative resistance," and contrasts them with what she terms "plantation futures" $(2013$, p. 8). These, she writes, "demand decolonial thinking that is predicated on human life" (2013, p. 3). Ramirez applies McKittrick's notion of black geographies and plantation futures to frame "black 
food justice projects [that] use the land as a tool of liberation, drawing from practices of resistance that stem from plantation survival strategies" (2015, p. 751), while Reese promotes the "geographies of self-reliance" at the heart of black food projects $(2018$, p. 408).

To help capture the racialized dimension of UA, we draw upon Omi and Winant's (1994, p. 2104) notion of "racial projects": which are "simultaneously an interpretation, representation, or explanation of racial dynamics and an effort to organize and distribute resources along particular racial lines." Sbicca and Myers (2017) draw on Omi and Winant in their treatment of UA as a racial project. Thus, UA projects shape and are shaped by deeply racialized social structures that place different populations in hierarchical and inequitable positions relative to the food system. We now turn to examining three types of UA projects, based on justice, health, and market taproots and their racialized natures.

\section{Justice-rooted UA projects}

Justice-rooted UA projects seek to transform a soil matrix of racial capitalism that disadvantages farmers of color, impugns their agricultural knowledge, and exploits, pollutes and appropriates their neighborhood spaces (Alkon and Agyeman 2011; Galli and Clift 2012; Gottlieb and Joshi 2010; Sbicca 2018; Slocum 2006, 2007). These projects closely align with the food justice movement, in which actors seek to politicize and transform the production and consumption of food in order to address underlying inequities in the food system (Alkon and Agyeman 2011; Alkon and Guthman 2017; Alkon and Mares 2012; Anguelovski 2015; Block et al. 2012; Galli and Clift 2012).

These scholars highlight the contributions and narratives of people of color in agriculture, using food as a lens through which to examine racial injustice, and by prioritizing support for food organizations led by people of color (Anguelovski 2015; Billings and Cabbil 2011; Hoover 2013; McClintock 2014; Passidomo 2014; Reese 2018; White 2017; Yakini 2013). These actors support food sovereignty, so that people of color can reclaim agency and control over their own food practices and systems, often in the face of corporate hegemony and state violence (Alkon and Mares 2012; Block et al. 2012). They also seek to revalorize the labor of black and brown workers who have built, and continue to power, the agricultural industry, at great emotional and physical cost to themselves (McKittrick 2011; Ramirez 2015). These UA actors also often support initiatives related to health promotion and entrepreneurship that are directed by and for people of color, in order to meet larger racial justice goals (Bradley and Galt 2014; Bradley and Herrera 2016; Reese 2018).

Several authors show that, while daunting, struggles for a just food system can be won, at least in part. Justicerooted organizations put forward a vision of change that acknowledges and addresses the oppressive and racist structures that are the underlying cause of the injustices of the food system. They do so by de-centering white actors in the food movement (Ramirez 2015), dismantling structural racism (Billings and Cabbil 2011), decolonizing the food system ${ }^{1}$ (Bradley and Herrera 2016; Grey and Patel 2015; Meyers 2015), and uplifting models of knowledge and leadership from communities of color (White 2017). Sbicca and Myers highlight the herculean task of liberatory food justice movements, as they "build counter hegemonic forms of power that transform race relations and institutional priorities" (2017, p. 38); they portray what they term "food justice racial projects" as ways to resist racialized urban neoliberalization (Sbicca and Myers 2017). White emphasizes the importance of examining history as a way to reframe people's relationship to land, in order "to challenge the persistent frame of agriculture as a site of oppression for African Americans," noting that "the richness and complexity that is our agricultural history can be detailed from a place of resistance" (2017, p. 10). Ramirez adds that, in the context of UA, "black geographies reinscribe the landscape with meaning, reproduce space in ways that challenge the plantation legacy, and refuse to succumb to the bleak and unjust present" (2015, pp. 758-759). In their utmost expression, justice-rooted UA projects are movements for abolition and liberation.

\section{Health-rooted UA projects}

Unlike justice-rooted projects, health-rooted UA projects do not seek to transform the fundamental matrix of the soil of racial capitalism. However, they do work to improve its potential to nurture the health and well-being of those who cultivate it. These projects critique the social and ecological destruction of industrialized agriculture, but do not directly confront the structural racism or neo-liberalism that support it.

UA projects with a health taproot align with some of the dominant narratives found in the alternative food movement. With a focus on health, nutrition, environmental quality, and the vitality of local food systems, UA movements frame social change as occurring both by educating people to help them reconnect to food, and by addressing food access and food deserts by increasing the availability and production of fresh, locally produced foods (Alkon and Agyeman 2011; Hardesty et al. 2014; Qazi and Selfa 2005).

Changing food systems through a health-rooted approach can, however, replicate social inequalities by assigning food

\footnotetext{
1 The metaphorical use of the term decolonization has been critiqued by Tuck and Yang (2012); we use it here only to reflect its use by these authors.
} 
a morality and universality. As Bradley and Herrera write, "local, sustainable, and environmentally friendly foods are assumed to be universally good," while the racialized inequities that shape these systems remain unexamined (2016, p. 6). Uncritically proclaiming the universal benefits of these foods and foodways often has the effect of reinforcing whiteness in the food movement, ignoring the experiences and contributions of people of color (Anguelovski 2015; Guthman 2011; Slocum 2006; 2007). In providing education to consumers about the benefits of local and sustainably produced foods, white-led or predominantly white organizations with a health-centric taproot that aim to "do good" by helping underserved communities and communities of color (Slocum 2007) can unintentionally end up reinforcing systems of white privilege and white supremacy (McClintock 2018; Minkoff-Zern 2014; Passidomo 2014; Reynolds 2015). They can also lead to the displacement of people color through racial "viscosity" (Ramirez 2015) which allows white people to claim black geographies as white spaces.

\section{Market-rooted UA projects}

Market-rooted UA projects largely accept the dominant racial capitalist mode of agriculture, but seek to harness it to drive local and regional economic development, ostensibly for universal benefit. Still, these projects tend to overlook the ways that their work relies upon and enables the reproduction of structural disparities at the heart of racial capitalism.

UA projects with a market taproot typically comprise farm-to-fork or vote-with-your fork events, in which food becomes a mechanism for engaging with the market, and supports a normative vision for social change (Allen and Guthman 2006). These movements are market-based in three ways. First, the proponents of these approaches promise to enlist the forces of the market to build assets and wealth for marginalized farmers, and in disadvantaged neighborhoods ( Daftary-Steel et al. 2015; Vitiello and Wolf-Powers 2014;). Secondly, however, these market-based relationships often also contribute to the exploitative impact of racial capitalist systems on labor and the subaltern classes (Cohen and Reynolds 2015). Third, market-based solutions can be understood as part of the neo-liberal retrenchment of state mechanisms of social regulation in favor of market actors, thereby placing responsibility for structural change on individual and consumer-based action (McClintock 2014; 2018). In this paradigm, farming enterprises and consumers are presented as the agents by which local food systems are transformed, in ways that ignore the underlying racialized logic of the larger agro-industrial system (Pudup 2008).

In sum, market-rooted projects typically approach race by focusing on what they see as disadvantaged populations in need of uplift and charity, but do not confront the institutional racism in capitalist systems themselves. This neo-liberal vision has been critiqued by scholars as being largely ineffective at creating systemic change, and as instead reinforcing racially oppressive and inequitable food systems (Alkon and Guthman 2017; Allen and Guthman 2006; DuPuis et al. 2006; Giménez and Shattuck 2011; Guthman 2011; McClintock 2014, 2018).

\section{Entangled roots}

Food justice scholarship tends to heavily critique health- and market-rooted UA projects, and praise justice-rooted ones. However, very few scholars have shown the specific ways and places in which these three forms of UA grow together. Notable exceptions are Pudup (2008), McClintock (2014, 2018), and Sbicca and Myers (2017, p. 8), who examine the contingent and inherently contradictory nature of UA. McClintock considers the role of racial capitalism in understanding the internal contradictions and contingency of UA, noting that "how [UA] is mobilized and by whom ... can make all the difference in whether it serves to bolster racial capitalism or to undermine it" (2018, p. 9). This entanglement is an understudied but important focus of future scholarship, as there are many symbiotic and competitive interconnections between the three UA roots, which together form interwoven networks. Without attention to these relationships between the roots and the soil matrix of racial capitalism, we argue, it is impossible to fully understand the complex nature of UA. It is this contingent and contested nature of UA that our analysis of distinct yet entangled roots seeks to illuminate. We offer the following case study to respond to this need.

\section{Case study context: Sacramento, California}

Sacramento provides an ideal setting in which to explore the relationship of justice-, health-, and the market-rooted UA projects with each other and with the soil matrix of racial capitalism.

Sacramento is a globally significant seat of agricultural power, and of environmental, economic and social policies. It is the capital city of California, a US state that, if it were a nation, would have the fifth largest economy in the world. The state's industrial agricultural system leads the US in cash farm receipts, and produces two-thirds of the country's fruits and nuts (California Department of Food and Agriculture 2019). At the same time, the dominance of the industrial agricultural model has produced a condition of "poverty amidst prosperity" (Martin and Taylor 1998), especially for the state's predominantly Latino farm workers.

Sacramento has a vital UA movement with many roots. The city has branded itself as the nation's Farm-to-Fork 
Capital, a UA project-described further below- of festivals, dining events, and tourism promotion that is largely white-centered and consumption-oriented. More broadly, the city has eight farmers markets, 54 school gardens, 17 city-run community gardens, 5 nonprofit-run community gardens, and at least 7 urban commercial farms. The city has passed local ordinances supporting the production and marketing of harvests from home and community gardens. It also has a small but growing food justice movement led by people of color that is simultaneously lauded in the local media and by local political elites and yet greatly underfunded by foundations relative to mainstream UA organizations.

Meanwhile, Sacramento remains a site of significant and growing social and economic inequities. Rental rates for housing are the third fastest-rising in the country (Yardi Matrix 2020), resulting in intense pressures of gentrification and displacement (Ho 2019). Until recently, a lack of rent control accelerated many residents' descent into housing poverty. Sacramento is also one of the most diverse cities in the state and country. There are over 121 languages spoken by city residents, and $34 \%$ of area inhabitants speak a language other than English at home (US Census Bureau 2018a). The city is also is highly segregated by race. The overall percentage of people of color in the City of Sacramento is $33.6 \%$, but the percentage of people of color ranges from $90 \%$ in some neighborhoods, to as low as 5\% in others (US Census Bureau 2014). African American children in Sacramento County die at twice the rate of children of any other race/ethnicity. ${ }^{2}$ Finally, Sacramento is a critical site for Black Lives Matter (BLM) organizing. This was brought to a flashpoint following the 2018 police killing of Stephon Clark, an unarmed Black man (Walker 2018); since then, related racial justice uprisings have continued in response to continued police killings and violence, joining the 2020 nationwide surge in BLM-related protests.

\section{Methods}

This article draws from data collected through a five-year transdisciplinary study of home gardening and soil lead in Sacramento, California (London et al. 2018). ${ }^{3}$ The research team (the first, second, third and fifth authors of this paper)

\footnotetext{
2 This statistic comes from The Black Child Legacy Campaign at https://blackchildlegacy.org/ (last accessed May 20, 2020).

${ }^{3}$ Lead can be deposited and persist in soil and around gardens from sources such as paint from older homes, automotive exhaust from the era of leaded gasoline, and historic and contemporary industrial emissions (Schwarz et al. 2016). Our study measured soil lead levels in and around home gardens to understand the relative health risks and disparities associated with home gardening (London et al. 2018).
}

consisted of scholars from UC Davis, University of Illinois, Urbana-Champaign, and University of Northern Kentucky). ${ }^{4}$ The overall study sought to understand the tradeoffs between the perceived benefits of home gardens (such as improvements in nutrition, mental health, aesthetics, neighborhood cohesion and pride) and the potential sense of danger, stigma and disempowerment provoked by the presence of soil lead in and around area gardening sites.

The study involved a collaboration between the university team and two community-based and Black-run UA organizations, Ubuntu Green and the Yisrael Family Urban Farm (YFUF). The study supported Ubuntu Green and YFUF to install over 75 home gardens in two racially and ethnically diverse and underserved urban neighborhoods in Sacramento and to partner with the university team's testing of soil lead levels in and around these gardens. Ubuntu Green's and YFUF's UA projects were in turn part of a larger strategy called Building Healthy Communities (BHC) funded by The California Endowment, a philanthropic foundation focused on inequities in the social determinants of health. The food, nutrition, and gardening strategy of BHC was coordinated by Soil Born Farms (SBF), a nonprofit organization dedicated to promoting urban gardening as a means of achieving healthy communities and a sustainable city.

Researchers conducted 24 semi-structured interviews. Interview participants included nine residents, nine intermediary UA or environmental organization leaders, and six policymakers. The sampling frame for the resident interviewees was structured to represent the ethnic/racial diversity of the home gardeners enrolled in the garden building program (African American, Latino, Asian American, and white), as well as those in the two project neighborhoods in north and south Sacramento. Interviewees were selected using a purposive sampling approach in each of these categories. The project team identified residents who seemed most engaged in the project and who were likely to be interested in participating in an interview. Although this selection process may have introduced some bias into the sample, it allowed researchers to analyze the narratives of those deeply engaged in UA projects. The sampling frame for the environmental organizational leaders and policymakers was developed through a scan of the most prominent leaders in their sectors. This identification relied on the first author's familiarity with the local UA community, gained through long-time engagement in the region. This process may also have introduced some sampling bias, but also insured that key actors were included in the pool of interview subjects.

The interviews were conducted using a semi-structured guide in participants' homes and offices, and lasted between

\footnotetext{
${ }^{4}$ The second and third authors have switched institutions since conducting the research.
} 
one and two hours. Using qualitative analysis methods (Welsh 2002; Miles and Huberman 1994), interviews were transcribed and coded with NVivo11, applying the key themes of experiences and perceptions of the social, cultural, political, economic, and health dimensions of home gardening and UA, as well as meanings associated with the physical conditions of the environment in the city. The racialized and entangled roots of UA were not the initial focus of the interviews, or of the broader study. Instead, this theme arose during the interview and analysis process, as a way to make sense of the diverse narratives associated with people's experiences of gardening, and their broader structural contexts. These themes were then integrated into the coding scheme to guide the analysis. It was in this context that the concept of racial capitalism emerged as a useful framework for understanding UA in Sacramento.

\section{Agriculture and Sacramento's racialized urban landscape}

Before exploring the contemporary manifestations of the UA movement, we will place it and its constituent projects in a deeper historical context, grounded in agricultural traditions and conflicts that long predate Sacramento's contemporary food movement. Sacramento's complex racial and ethnic mosaic is shaped by the material processes associated with the development of natural resource and agricultural industries in and around the city. These processes are based in histories of discursive and physical violence provoked by successive displacements and relocations of racialized populations, their incorporation into racialized systems of labor, and the resulting production of racialized urban and peri-urban landscapes. At the heart of all of these processes are the workings of racial capitalism, including the ideology of white supremacy, which underwrites multiple techniques and technologies of racist violence by the combined forces of capitalism and the state (Almaguer 1994). These racialized logics form the soil matrix in which the current agrosocial landscape of Sacramento is cultivated.

This violent history begins with the genocide of and land theft from Native Americans by European missionaries, traders, settlers, and gold miners, and by massacres of Native Americans throughout the 1700s and 1800s (Heizer et al. 1977; Heizer 1993; Hurtado 1988). ${ }^{5}$ The colonization and conquest of Mexico's Alta California by the US opened

\footnotetext{
5 In the past two decades, environmentally-oriented economic development by area tribes such as the Yocha Dehe Wintun Nation has begun to rebuild this land-based tenure and stewardship. See, for example: https://www.sekahills.com/story/sustainable-practices/ (last accessed August 13, 2019).
}

up a land rush, and later a gold rush, in the Sacramento area (Griswold del Castillo 1998; Cameron 1998).

Starting in the 1870s, the demand for agricultural labor was filled by tens of thousands of Chinese immigrants (Gambirazzio 2009; Leung and Ma 1988) whose prominence on Sacramento's rural fringes was in part a result of their exclusion from the urban core, through violence and policies of enforced segregation (Leung and Ma 1988). With the rise of anti-Chinese racist violence in the late 1880s, (Saxton 1995) Chinese agricultural laborers were increasingly replaced by Japanese immigrants, followed by Filipino and Mexican immigrants. All of these groups were considered exploitable, both because of their political marginalization, and because of racist ideas about the supposed suitability of non-white bodies for backbreaking labor (McWilliams 2000). The Japanese presence in Sacramento area agriculture rose to a peak in the years before World War II, and then declined precipitously due to the federally ordered wartime internment of Japanese people (Azuma 1994; Wilson 2010). From 1942 to 1964, the Bracero agricultural labor program brought thousands of Mexicans to work in area farms, filling a labor shortage created by the military deployment of a largely white male military force, and by the internment of Japanese Americans (Mitchell 2010). Mexicans and Mexican Americans soon represented the vast majority of Sacramento area's agricultural labor force, and continue to power the region's agricultural industry today (Holmes 2013; Martin 2011a, b).

African American settlement in the Sacramento region began during the post-Civil War Reconstruction era in the late 1800s, and picked up during World War II, due in part to the growing exodus of Black Americans fleeing racial violence in the US agricultural South (Dingemans and Datel 1995; Datel and Dingemans 2009; Datel 2018). Racially restrictive covenants concentrated African Americans in what were then outlying neighborhoods in north and south Sacramento (Hernandez 2009, 2014). Some of these neighborhoods were designed with lots able to accommodate the agrarian practices that African Americans carried with them (Dingemans and Datel 1995), with traces of this agricultural heritage still present today. Starting in the 1980s, many of these neighborhoods have faced gentrification and displacement, due to successive rounds of urban restructuring. For example, one neighborhood of south Sacramento's Oak Park that once formed the core of Black culture in Sacramento has experienced a drop in its Black population from 65\% in 1970 to $28 \%$ in 2018 (US Census Bureau 2018b).

In the period following the Vietnam War in the 1970s, refugees from Laos, Cambodia, and Vietnam, many of them from ethnic groups such as the Hmong and Mien, who fought alongside US military forces, fled to resettlement gateway cities such as Sacramento (Helzer 1994; Sowerwine et al. 2015). Many of these refugees had been rural 
villagers, practicing subsistence agriculture. Once resettled in Sacramento's urban neighborhoods, some families were able to establish small-scale farms, usually on rented lands, while others developed home gardens for food and medicinal purposes (Corlett et al. 2003).

White settlement over the past century has involved migration of people of multiple white ethnicities, often into neighborhoods with the racially-restrictive covenants mentioned above and benefiting from government programs such as home and business loans among others (Hernandez 2009, 2014). This systemic racism has created a pattern of domination of political and economic life. White people and white-run organizations also predominate in the UA movement. Most recently, lower-income immigrants from eastern Europe have become involved in community gardening.

These centuries-long historical dynamics of racialized agriculture in and around Sacramento highlight the city's place in a global nexus of racial capitalism. Racial and ethnic diversity is considered one of Sacramento's strengths, but it has also been the basis of significant conflict over time. These dynamics continue to play out in the contemporary UA movement, in ways that we will illustrate below.

\section{Promoting UA in Sacramento}

To begin unearthing the three individual taproots of the UA movement in Sacramento in the contemporary moment, it will be useful to highlight one instance in which all three have been entangled in a major victory-one built on a long history of urban gardening in the city (Cutts et al. 2017; de la Peña 2015; Napawan and Townsend 2016).

In 2012, the Sacramento Urban Agriculture Coalition (SUAC) was formed as an off-shoot of the Healthy Food for All Collaborative, a partnership of many of the UA organizations in Sacramento. SUAC's goal was to bring together over a dozen organizations drawn from multiple movements, including the environmental, UA, legal aid, community development, and other movements around a key policy challenge: supporting UA through land use, zoning, and health codes. The SUAC represented a symbiosis of all three of the major taproots of UA organizing in Sacramento, which had joined to work for a common cause. The coalition described itself as follows.

The Sacramento Urban Agriculture Coalition is ... dedicated to addressing issues of food access, economic resilience, and neighborhood blight in order to advance the health and well-being of all Sacramento residents (City of Sacramento 2012).

To achieve this broad goal, the SUAC set its sights on influencing the City of Sacramento's 2012 General Plan update. Through years of heated negotiations, the city and the SUAC developed a proposed ordinance that would allow for the sale of produce from home and community gardens, as well as the protection of community gardens, and other provisions. In March 2015, the Sacramento City Council approved the agriculture ordinance in its packed chambers, with scores of residents and garden activists in attendance. Many of these were African American, and included Hmong and other Southeast Asian refugee urban farmers. Following its victory at the city, the coalition achieved a second victory, successfully pressuring Sacramento County to adopt a similar ordinance.

While the coalition shared the unified goal of passing the ordinance, its members had a wide variety of motivations. For justice-rooted actors, the ordinance represented economic empowerment and a validation of their agricultural expertise; for health-rooted organizations, it meant an increase in the supply of local nutritious food; and for market-rooted organizations, it meant the monetization of formerly non-market activities. ${ }^{6}$

On one level, the development of the SUAC, and the passage of the Sacramento Urban Agriculture Ordinances illustrate a convergence between different roots of the region's UA movement. However, if we unearth a deeper structure, and examine the relationships between these roots as they inhabit the soil matrix of racial capitalism, we can discern both their entangled and distinct natures. It is to this project of unearthing and disentangling that the narrative now turns.

\section{The three taproots of UA in Sacramento}

\section{Justice-rooted UA: "not gardening in English"}

Justice-rooted UA can be seen as part of a resistance movement to the racialized processes that place communities of color in marginalized positions, both in food systems, and in the mainstream food movement. The justice-rooted approach is grounded in an analysis of racial capitalism, and of the process by which the state and capital have conspired to oppress and exploit people of color. This process began with the first wave of European settlement of the Sacramento Valley, and continues today through the criminalization and devaluation of Black and brown bodies, their labor and basic humanity, through disinvestment, gentrification, displacement, and the violence of economic deprivation.

Justice-rooted UA advocates seek to contest these deep agricultural legacies, which are normalized, rendered

\footnotetext{
${ }^{6}$ Sounding a note of caution about urban farming ordinances, Havens and Roman-Alcalá (2016) observe that urban gardening ordinances can have the unintended consequences of aiding neo-liberal urban development processes (particularly gentrification)
} 
invisible, and buried underground. They seek alternatives to the de facto racial segregation that locates Black populations and other populations of color in food deserts, with few options to procure fresh and nutritious food. They work to move people of color from the margins to the center of the food movement, which is otherwise dominated by white-led organizations. Their work parallels Gilmore's challenge to build an abolition geography by "changing places" (2017), for example, by changing south Sacramento landscapes from ones that reproduce social relations rooted in slavery, into regenerative and health-giving landscapes, where people mix their labor with the soil as a practice of freedom (Ramirez 2015; White 2017). In this way, justice-rooted UA activists produce liberatory alternatives to the plantation legacy, and enact versions of a redemptively Black sense of place (McKittrick 2011; 2013; Ramirez 2015; Reese 2018).

A common narrative about the evolution of the UA movement is that it was originally the creation of white-led alternative food network organizations that have recently begun to incorporate people of color. However, this version is increasingly met by a counter-narrative, in which engagement in UA by people of color does not represent a new phase or constituency of the UA movement, but rather signifies that the UA movement has finally caught up to the long-standing farming and gardening practices of these populations. Many justice-oriented UA activists take pains to point out that these practices both predate the contemporary variation of the 'foodie' movement, and extend far beyond the movement's white-coded racial identity. This analysis is not only factually corrective. It is also politically redemptive, as justice-rooted activists take aim at elements of racial capitalism that devalue Black and brown bodies and their labor, and place them in subaltern material and discursive positions in state and market systems.

Fatima Malik, a community activist of South Asian descent who was interviewed as part of the study, critiqued the racialized discourse that symbolically and materially excludes farmers of color, and proposed an alternative framework of resistance and cultural affirmation.

But I think from a racial perspective ... I think the garden community ... it seems like it's a white thing, you know? Because you hear more about like, let's say, 'white people garden'; But, the Hmong people, they garden. They're just-not gardening in English, I guess. Right? Like, so, you just don't know about it because it's not in English of the whiteness of urban ag.

Fatima credited her ancestors, which include farmers in the Pakistani Punjab region, with her own interest in gardening.

I recognize that my ancestors, and not too far removed, were farmers. And even to this day the region of Punjab is very fertile and rich. And a lot of farming still happens there. So, from that perspective I wanted to, kind of, reconnect to that ...

Ubuntu Green, a Sacramento-based environmental justice organization, embraced a similar vision of a racial justice-grounded UA movement. Founded in 2009 by Charles Mason Jr., a Black environmental justice advocate, it was a multi-racial organization based on the concept of Ubuntu, a Bantu-language term meaning shared humanity, generosity, and common effort. It ran a number of community development programs, including one on UA. Ubuntu Green gained funding from an urban gardening component of The California Endowment's BHC initiative (coordinated by SBF) to install gardens in dozens of home gardens in disadvantaged communities in south and north Sacramento.

When Ubuntu Green closed its doors in 2015, the YFUF's "We Diggit" program took up this charge; it has continued to build gardens, and advance food literacy and career pipelines into the food and farming sector for low-income youth of color. The YFUF is truly a family enterprise run, by Chanowk and Judith Yisrael, a Black couple, and their children in south Sacramento. It combines training in home gardening, medicinal and value-added food production, and youth leadership in UA. This is all done to realize the family's vision of "Transforming the Hood for G.O.O.D" (Growing Our Own Destiny.) A partnership with SBF helped fund the home garden installation program of the YFUF, though members of the Yisrael family had been involved in food and agriculture for several years before this collaboration.

Chanowk Yisrael described the origins of his gardening, not in an explicitly social or racial justice framework (that would come later), but as obeying the twin imperatives of self-sufficiency and health.

[In] 2008 ... I'm trying to figure out how I'm going to continue to keep putting good healthy food on the table. And, either I' $m$ going to have to grow some food or I'm going to have to figure out a way to make a whole bunch more money. And so, my, my idea was to start to grow food in the back yard ... It was not urban farm. It was not to help the community. I've always been sensitive to what's going on in the community because I grew up in those conditions and if I had the ability to do it, I would have loved to have been able to give back. But it wasn't for that reason that I started growing food, it was just really to be able to grow food, eat healthy food, and then be able to feed my family.

Having started with this embodied scale and food sovereignty objective, Yisrael now places his family's experience in a larger political economic perspective, one that critiques capitalism's extractive model of value. 
The whole idea of this society that we live in where, where you're taught not to create your own value. You're always looking for values somewhere else. And that's just the nature of a capitalistic society is that ... somebody's got to get exploited somewhere. So, and it's usually the people that are, you know, on the bottom that are getting exploited. So, the idea of creating your own value, food, clothing, shelter, becoming self-sufficient, that's what America was, was built on.

This notion of food sovereignty and the creation of one's own value contains both a critique of the capitalist system, but also a strategic engagement with it. The complex relationship between market-rooted UA in the YFUF UA's project arises as it seeks to help gardeners and farmers of color create value-added agricultural products for home use and for sale, and train youth for careers in food and agriculture while maintaining a critique of the inequities of the capital system.

Yisrael addresses critical elements of the racial capitalist order that devalues and criminalizes Black bodies and stigmatizes Black-coded spaces, by recounting a personal story of 'gardening while black.' In it, he offers an example of the negative consequences of being surveilled as a racial Other in the space of a neighborhood community garden.

But I think the key environmental concern for me is how people are perceived to be that live here. Because the police already think we're all criminals. I know because I've been at the garden at 14th and 44th and I've have been put in handcuffs ... Obviously, somebody must have thought I was breaking in so they called the police. You know, that type of thing. So, I've ended up in handcuffs a couple of times, which, you know ... 'Hey, I'm a farmer ... I mean if you wanted some squash, you could have just asked me." [Laughs]

To counter these physical and discursive assaults, Yisrael linked his work to long-standing racial justice movements such as the Black Panther Party, with their emphasis on selfsufficiency and food sovereignty as a form of community empowerment.

Interviewer: So, I wonder ... how do you see yourself relative to some of those other, even more explicitly revolutionary movements, or like, radical AfricanAmerican movements?

Yisrael: I don't see us any different. I mean because before you can do what they did, you have to have food, clothing and shelter. And so, I think of it as we're building an infrastructure to bring our communities back ... In order to start a revolution, whether it's political, social, violent or whatever, you have to live with the people ... If you want food, you have to be where the soil is and you have to do the work in the soil. So, we look at ourselves as right now we're just getting the soil ready ... We haven't even started doing anything yet because we're just now getting the soil ready so that when we do finally put those seeds in there, you'll see the growth explode.

In this way, Yisrael and the YFUF seek to transform soil that has been poisoned and depleted through racialized violence, back into a regenerative medium where justice-rooted UA projects can germinate and thrive. In doing so, he also draws on some health-rooted values, by pushing for access to nutritious food, and building market-rooted projects to support the self-sufficiency of Black farmers and families.

Justice-rooted visions are also found in the city's political leadership. In a similar way to Yisrael, Phil Serna, a Latino member of the Sacramento County Board of Supervisors (and son of Sacramento's first Mexican-American mayor, Joe Serna) highlighted the formative role of agriculture in his family. He is bemused by recent efforts to brand Sacramento as the farm-to-fork capital.

With a family including my extended family that was, they themselves were migrant farmworkers and very active in the farmworker rights movement during the ' $60 \mathrm{~s}$. And hearing some of the stories about, things like being sprayed with pesticides and crop-dusted while harvesting crops. Certainly have an appreciation for the toil of what it means to, to be a farmworker ... Not that we, we thought it was shameful. Not at all. But, it was a very tough life. I think it's kind of funny in retrospect that there's a generation of Sacramentans, people that reside in this region that just think it's this incredibly novel idea that we embrace our heritage as a food producing region, when I never thought we lost it. I, to me, it was always part of who we were.

Serna's puzzling over the historical amnesia in the mainstream, mainly white-led foodie world was coupled with a critique of a recent regional agriculture plan by a local non-profit organization to promote the Sacramento region's farm-to-fork brand.

But what was glaring, the glaring omission for me: it was, there's nothing in it about social justice. There was nothing in it that it even began to acknowledge who it is that actually produces the food. And I'm not just talking about the people that harvest the food, the farmworkers. Even the farmers.[T]here has been such a focus and heavy concentration on the product and not the producers.[N]ot to be overly abrasive about it in the context of that forum, but I did point it out and the authors of the plan that were there, were a bit embarrassed by the truth and said, you know, 'No one has really asked the question about, you know, about what is it that we should be thinking ... about it as a region 
when it comes to the social equity of food production?' And I think that's where we really, if we're going to continue to embrace that as, as part of who we are as a region, I think we necessarily have to also embrace the social equity involved in food production, harvesting.

The authors of the regional agricultural development plan had focused their work on small-scale agriculture in the urban core, not on labor relations in the industrial agriculture on its rural periphery, yet they missed the diversity in Sacramento's UA as well. Serna's critique exemplifies many of the perspectives expressed by justice-rooted activists: they critique the ways that the market-rooted parts of Sacramento's UA movement marginalize workers and people of color. Serna's challenge has been to reimagine the Sacramento region from the perspective of social and racial justice, focusing on issues of production in the food system. This approach is typical of the justice-rooted model: it blends a critical analysis of labor relations, with an understanding of the structural changes needed to rebalance the scales in favor of farm workers, as and attend to the well-being and empowerment of communities of color.

\section{Health-rooted UA: from counterculture to deli counters}

Health-rooted UA projects focus on reconnecting people to their food, and improving public health through gardening education, the expansion of community gardens, and policy advocacy. We describe this movement as health-rooted to refer to the ways it has directed agricultural interventions to address the degradation of human and ecological health associated with the modern food system. This activity aims to produce empowered and educated subjects with sovereignty over their own diets.

The engagement of these UA projects with racial capitalism centers on a critique of capitalism's impacts on the health of the land and human bodies. While this has begun to change in recent years, these projects generally lack an analysis of structural racism that would allow them to specify whose bodies are being particularly affected by racial capitalism, and to distinguish the historical and structural factors that produce food inequities. Furthermore, in some cases, organizations in this movement exacerbate the marginalization of people of color by reproducing a white, normative, agrarian imaginary, through an allegedly color-blind optic. Their education projects — even when well-intentioned-can devalue the food ways and knowledge of people of color (Minkoff-Zern 2014). Many of these organizations benefit from the white privilege of their leaders, who can mobilize social and financial capital to grow their programs. It is simply not part of their core mission to explicitly challenge structural racism in the food system. Still, some area groups, such as SBF, are increasingly seeking to be inclusive and supportive of UA organizations led by people of color, and that are located in diverse neighborhoods.

The evolution of the UA movement in Sacramento is grounded in the countercultural movements of the 1970s and early 1980 s. Like those elsewhere in the US, these movements were generally led by white activists and farmers who sought alternatives to industrialized food systems, and to the degradation of urban environments, with its associated public health crises. The establishment of the Sacramento and Davis Food Co-ops in the 1970s, and local and organic farms such as Yolo County's Full Belly Farm and Good Humus Farm in the early 1980s, exemplified the counter-cultural Zeitgeist of the time. Shawn Harrison Co-Director of SBF, a white man and leader in Sacramento's health-rooted UA movement, recalled that in the late 1990s, there was:

Some conversation that was beginning to happen around like, 'well what is the role of the city with respect to food?' And, you know, 'what are we going to do to get healthier food into our communities'? We've historically been an agricultural region, but we're becoming disconnected from that. How do we preserve that heritage, how do we preserve that identity? But it was still very much, in my opinion, agriculture was very much the step-child. Wasn't fully embraced, and it needed some awareness and a little love.

In this environment, Harrison, along with SBF Co-Director, Janet Zellen, a white woman, and a third co-founder Marco Franciosa, a white man, developed their first urban farm on the outskirts of Sacramento in the early 2000s, with the mission of demonstrating the feasibility of organic farming in urban environments, and improving the supply of healthy food to area residents. Harrison recounts that his desire to grow food drew on a long lineage of farmer practitioners dedicated to the embodied practice of cultivating the land. He viewed this "hands in the soil" practice as a meaningful way to sustain healthy bodies and, by extension, to improve the health of communities and the land. Harrison emphasized that this craft knowledge was transmitted to him from a diversity of mentors, including people of color, as well as white farmers.

In the early 2000s, SBF brought together early agricultural innovators with organizations bent on improving nutrition access, such as the Health Education Council, area hospitals, and local chefs seeking to offer fresh and local ingredients. SBF developed its own small-scale demonstration farm and garden-based learning programs for schoolchildren, using models such as the Edible Schoolyard in Berkeley, and the Student Farm at UC Davis. Then in the mid-2000s, the movement took off, as philanthropic foundations began to invest in SBF and its broader network of 
organizations. In the years since, SBF has become a hub organization, helping coordinate multiple organizations' efforts to promote UA and sustainable food systems (de la Peña 2015). SBF has also provided training, and supported the funding for, food justice organizations such as YFUF, expanding their education programs throughout disadvantaged communities in Sacramento. SBF has also contributed to the region's UA movement through complementary efforts such as the healthy food campaigns of the Food Literacy Center, Health Education Council, and the Sacramento Food Policy Council (Napawan and Townsend 2016).

It is important to note that health-rooted UA projects are not only led by white people, and are not always grounded in white-coded projects. These UA projects have complex, racialized dimensions. For example, an African American woman from Del Paso Heights, a disadvantaged neighborhood of Sacramento where low-income people of color and immigrants predominate, described her motivation for working on her UA project as follows.

The gardening aspect that I got involved in was looking at healthier eating options in the community of Del Paso Heights. I was working with a nonprofit organization ... which is an organization with professional African-American women who focus on community service. We wanted to really target in on using empty lots in the neighborhood and show how we can go back to the times that I had grown up where a lot of people actually in the neighborhood had their own gardens, and we thought we could implement that back into the community and teach the younger generations about gardening. It's less expensive, it's healthier, and I think it's very therapeutic.

This quote speaks to the ways in which healthy eating can have a redemptive value in communities of color, but also reminds us how class privilege can shape the work of organizations that set out to 'teach the poor how to eat.' This quote identifies a route to social and physical transformation through individual behavior, rather than through structural change (e.g., challenging the racialized urban political economy that leads to so many empty lots in communities of color). More broadly, it points to the need to trace the intersectional relationships between race class, gender and other factors in order to understand the mutual entanglements of health- and justice-rooted UA projects, in a matrix of racial capitalism.

\section{Market-rooted UA: branding Sacramento}

Market-rooted UA projects focus on using the power of capital, constructing a consuming public to transform the local and regional economy. Their racialized UA projects tend to reinforce a white imaginary of the food system, and downplay or even obscure its inequities, dehumanization, and historical systemic violence. They adopt a neo-liberal stance that minimizes the role of the state in regulating capital and addressing structural problems in the market. Instead, they emphasize the primacy of individuals as consumers, as opposed to individuals as political actors capable of driving social change.

Over the past two decades, there have been a range of market-based economic development strategies to boost the region's agricultural sector and food system by local governments, chambers of commerce, and agricultural trade organizations. Starting in the late 1990s, the focus was on maintaining the viability of the region's agriculture industry by protecting farmland from urban and suburban sprawl. In the early to mid-2000s, this was followed by efforts to link agriculture to rural economic development and health. At this time, these strategies sought to catalyze agricultural clusters, build localized food production, invest in processing and consumption webs, seek investment in agriculture high technology (including rural broadband), and promote the brand of Sacramento agriculture as a regional economic driver. However, there was little attention to UA, and virtually no engagement with issues of racial justice.

In 2012, Mayor Kevin Johnson, the city's first Black mayor, proclaimed Sacramento as the nation's "Farm-toFork Capital" in an effort to re-position the city from a "cow town" to a vital center of economic innovation. ${ }^{7}$ The Farm-to-Fork campaign orients its work around four values: health, the economy, the environment, and community. In theory, these values leave room for connecting with healthand justice-rooted UA projects. In fact, however, they make the role of the market and the construction of a consuming public their driving and mediating forces. Absent in their materials is any mention of the causes of food injustice, or any reflection on potential collective action or public sector solutions. The hunger and food insecurity of hundreds of thousands of the region's residents is described as exceptional and paradoxical, as opposed to being an intrinsic part of a food system that places low-income people and people of color in subordinate positions. This framing allows the dominant agro-industrial order to evade critical scrutiny. Little to no attention is paid to the poverty wages of many farm workers, or the de facto segregation of people of color in food desert neighborhoods. In this market-rooted UA project, Sacramento's food system crisis of is understood to be a temporary glitch or shortcoming, to be solved by means of charity through food banks-an approach that does

\footnotetext{
7 Johnson, a former National Basketball Association All Star, and a native of Sacramento, has played an important but controversial role in spurring revitalization in his home neighborhood of Oak Park. This work has had a strong African American theme, but has also raised concerns about gentrification.
} 
not address the racialized drivers of food insecurity (Poppendieck 1999).

Sacramento's self-branding is exemplified by the city's renowned Tower Bridge Dinner, launched in 2013. To participate, would-be diners are asked to submit a lottery form to win the opportunity to buy $\$ 240$ tickets. Only 80 tickets are available to the public, with the remaining 720 slots allocated to corporate sponsors, with each ticket priced at over $\$ 600$. Diners are treated to al fresco feasting on Sacramento's iconic golden Tower Bridge, with fare that includes produce from area farms prepared by local celebrity chefs. To its credit, the proceeds of this exclusive event are directed to supporting educational events about the region's UA, including university scholarships for the children of farmworkers. Still, the dinner lays bare the tensions between the extensive wealth generated by the region's food system, and the ways in which this wealth is distributed. It also demonstrates with impeccable clarity how UA projects can be coopted for elite purposes. The contributions of the farmworkers, who actually produced the bounty for the celebratory dinner, are largely erased. Instead, the public is treated to a largely white and consumption-oriented image of agriculture and food, one that mirrors the racialized discourse in the region's agricultural system as a whole.

More recent efforts, facilitated by the Sacramento-based nonprofit organization Valley Vision, have infused a broader set of perspectives into the Farm-to-Fork initiative. According to Trish Kelly, a long-time local and regional economic development consultant, these efforts aim to build a vibrant agricultural entrepreneurship ecosystem, one that includes business development, financing, and workforce development training. Overall, Kelly describes the imperative of scaling up and capitalizing smaller UA projects by calling for more investments in UA and outlining critical questions for local elected officials.

[W] hat is the political support on the part of the city and the county? They've passed ordinances, which is great. What is the investment support to activate the concept? ... So, if it's a for-profit, are there mechanisms that they're financing or their loans or like you do to any other small business? ... But I think if you're going to treat people like Yisrael Family Farms as an enterprise and you want to activate small business entrepreneurship, especially in low-income communities, what part of a strategy is that? Like any other small business, they need connection to resources, right? I think there could be an advocacy role there if it's enough at scale where you go to Community Capital or Opening Doors and say, "Hey, we got 10 entrepreneurs in the queue for this. Why don't you develop a cohort to really get some content expertise about what it's like to do this kind of a small business versus others?"

This approach promises to expand the scope of benefits of the market to farmers of color. Still, it does not consider the ways in which racial capitalism itself is marginalizing and in some cases destroying black geographies. The engagement of food justice organizations such as the YFUF in such market-rooted visions is a double-edged sword. The YFUF seeks access to markets to sell the produce from its and other urban farms, but in doing so, risks having its more critical political projects blunted through a dependence on actors and systems that do not share its radical commitments, and may in fact oppose them.

\section{Conclusion}

The framework of racial capitalism and racially-organized UA projects offers a powerful way to unpack the racialized dynamics of UA. Applying this framework to the specific case of Sacramento helps unearth many of the key tensions and synergies that dominate complex, local ecosystems of entangled justice-, health-, and market-rooted UA projects. As we have seen, there are many points of connection and even symbiosis between the taproots of these different UA projects. Thus, for example, coalition-building fora, such as the Healthy Food for All Collaborative work on issues ranging from promoting herbicide-free schools, to fruit tree planting in disadvantaged neighborhoods, to developing large-scale facilities to support home and community gardens. Likewise, the alliance of justice-, health-, and marketrooted organizations in the SUAC was critical in pushing the Sacramento City Council and the Sacramento County Board of Supervisors to pass their respective Urban Agriculture Ordinances.

Justice-rooted projects emphasize the need to develop markets for home-grown produce, and empower agricultural entrepreneurs in communities of color; this work clearly resonates with that of market-rooted UA projects, which focus on the power of the market to transform communities and regions. At the same time, justice-rooted organizations pay attention to promoting healthy eating in communities of color, through home gardens, farm stands and farmers' markets, clearly echoing the focus on dietary concerns of healthrooted movements. Meanwhile, some health-rooted organizations, such as the SBF, support the mobilizing resources for many justice-rooted organizations, such as the YFUF. The health and justice roots of the UA movement are clearly linked through these organizations' shared appreciation for restoring people's connection to the soil-a connection severed by industrial agriculture - through embodied individual and collective experiences of UA. 
On the other hand, as we have seen, the taproots of UA projects are embedded in different racial matrices, in ways that often place them in divergent subjective and political positions. Market-rooted UA projects can potentially mobilize resources to support justice- and health-rooted organizations. However, their emphasis on the market can also limit the depth of these organizations' transformative effects on the soil of racial capitalism. True, both kinds of UA projects seek to open spaces for people repair ruptures with the soil. However, it is important to recognize that the ruptures they seek to repair have been caused by racially-specific histories. That is, while both white and non-white residents have been distanced from the soil by industrial agriculture, people of color inhabit a very different ecological landscape than many white people do. Their relationships to racial capitalism have been shaped by deep histories of racial violence both by the state, and facilitated by the state, including centuries of expropriation and segregation. More broadly, justice-rooted projects can be seen as a form of resistance to the marginalization of people of color in both health- and market-rooted projects, and ultimately seek a practice of abolition (Gilmore 2017), the achievement of liberatory black geographies, and versions of a restorative, Black sense of place (McKittrick 2011, 2013; Ramirez 2015; Reese 2018; McCutcheon 2019).

In sum, the organic metaphor we have used in this paper, of UA taproots growing in a racial capitalism soil matrix, offers a range of insights for UA scholarship. Understanding root-to-root and root-to-soil interactions can help distinguish the underlying racial logics of and relationships between different kinds of UA projects. One can see more clearly how UA projects that grow from different taproots can interact in competitive and symbiotic ways. Thus, justice-, health-, and market-rooted UA movements may undertake similar activities, establishing community gardens or pushing for passage of UA ordinances. However, their efforts are often directed to ends that are distinct, though not necessarily mutually exclusive.

UA projects remain sites of struggle. As long as Black farmers like Chanowk Yisrael can be handcuffed in community gardens, and as long as a ticket to a Sacramento Farm-to-Fork dinner can cost as much as an entire month's salary for a low-income community gardener, then understanding the power of racial capitalism will remain critical. For racial capitalism functions as a soil matrix that suppresses the growth of all living things that contradict its logic (i.e., justice-rooted projects); domesticates those that might otherwise be a threat (i.e., health-rooted projects); and enhances the proliferation of UA projects based on white privilege (i.e., market-rooted projects). A taproot and soil matrix analysis can help unearth these entangled legacies, and clarify the growing possibilities for liberation offered by UA movements in Sacramento, and elsewhere.
Acknowledgements The authors wish to acknowledge the generosity of the urban agriculture movement leaders in Sacramento for sharing their stories and insights to form the basis of the paper. We thank Shawn Harrison, Trish Kelly, and Chanowk Yisrael for their careful reading and valued comments. The authors also thank Dr. Krystyna von Henneberg of Creative Language Works for her skillful copy editing.

Open Access This article is licensed under a Creative Commons Attribution 4.0 International License, which permits use, sharing, adaptation, distribution and reproduction in any medium or format, as long as you give appropriate credit to the original author(s) and the source, provide a link to the Creative Commons licence, and indicate if changes were made. The images or other third party material in this article are included in the article's Creative Commons licence, unless indicated otherwise in a credit line to the material. If material is not included in the article's Creative Commons licence and your intended use is not permitted by statutory regulation or exceeds the permitted use, you will need to obtain permission directly from the copyright holder. To view a copy of this licence, visit http://creativecommons.org/licenses/by/4.0/.

\section{References}

Alkon, A., and J. Agyeman. 2011. Cultivating food justice: Race, class, and sustainability. Cambridge, MA: MIT Press.

Alkon, A., and J. Guthman. 2017. The New food activism: Opposition, cooperation, and collective action. Berkeley, CA: University of California Press.

Alkon, A., and T.M. Mares. 2012. Food sovereignty in US food movements: Radical visions and neoliberal constraints. Agriculture and Human Values 29 (3): 347-359.

Allen, P., and J. Guthman. 2006. From 'old school' to 'farm-to-school': neoliberalization from the ground up. Agriculture and Human Values 23 (4): 401-415.

Almaguer, T. 1994. Racial fault lines: The historical origins of white supremacy in California. Berkeley, CA: University of California Press.

Anguelovski, I. 2015. Alternative food provision conflicts in cities: Contesting food privilege, injustice, and whiteness in Jamaica Plain, Boston. Geoforum 58: 184-194.

Azuma, E. 1994. Japanese immigrant farmers and California alien land laws: A study of the Walnut Grove Japanese community. California History 73 (1): 14-29.

Billings, D., and L. Cabbil. 2011. Food justice: What's race got to do with it? Race/Ethnicity: Multidisciplinary Global Contexts 5 (1): 103-112.

Bledsoe, A., and W.J. Wright. 2019. The anti-Blackness of global capital. Environment and Planning D: Society and Space 37 (1): 8-26.

Block, D.R., N. Chávez, E. Allen, and D. Ramirez. 2012. Food sovereignty, urban food access, and food activism: Contemplating the connections through examples from Chicago. Agriculture and Human Values 29 (2): 203-215.

Bradley, K., and R.E. Galt. 2014. Practicing food justice at Dig Deep farms \& Produce, East Bay Area, California: Self-determination as a guiding value and intersections with foodie logics. Local Environment 19 (2): 172-186.

Bradley, K., and H. Herrera. 2016. Decolonizing food justice: Naming, resisting, and researching colonizing forces in the movement. Antipode 48 (1): 97-114.

California Department of Food and Agriculture. 2019. Agricultural statistics review: 2018-2019. California Agricultural Statistics Review. Sacramento, CA: California Department of Food and Agriculture. https://www.cdfa.ca.gov/statistics/PDFs/2018-2019A gReportnass.pdf. Last accessed 1 June 2020. 
Cameron, C.D.R. 1998. Friends or enemies - the status of Mexicans and Mexican-Americans in the United States on the sesquicentennial of the treaty of Guadalupe Hidalgo. Southwestern Journal of Law and Trade in the Americas 5: 5-26.

City of Sacramento. 2012. Planning and Design Commission Staff Report. https://sacramento.granicus.com/MetaViewer.php?view_ id=34\&clip_id=3497\&meta_id=423597. Last accessed 1 October 2019.

Cohen, N., and K. Reynolds. 2015. Resource needs for a socially just and sustainable urban agriculture system: Lessons from New York City. Renewable Agriculture and Food Systems 30 (1): 103-114.

Corlett, J.L., E.A. Dean, and L.E. Grivetti. 2003. Hmong gardens: Botanical diversity in an Urban Setting. Economic Botany 57 (3): 365 .

Cutts, B.B., J.K. London, S. Meiners, K. Schwarz, and M.L. Cadenasso. 2017. Moving dirt: Soil, lead, and the dynamic spatial politics of urban gardening. Local Environment 22 (8): 998-1018.

Daftary-Steel, S., H. Herrera, and C.M. Porter. 2015. The Unattainable trifecta of urban agriculture. Journal of Agriculture, Food Systems, and Community Development 6 (1): 19-32.

Datel, R. 2018. Eleven more events that have shaped Sacramento's human landscape. The California Geographer 57: 1-22.

Datel, R., and D. Dingemans. 2009. Immigrant space and place in suburban Sacramento. In Twenty-first-century gateways: Immigrant incorporation in suburban America, ed. H.G. Ciseneros, 171-199. Washington, DC: Brookings Institution Press.

de la Peña, D. 2015. Edible Sacramento: Soil born farms as a community-based approach to expanding urban agriculture. In Incite CHANGE/CHANGE Insights: Council of Educators of Landscape Architecture (CELA) 2015 Conference Proceedings, 37-52. Manhattan: Kansas State University.

Dingemans, D., and R. Datel. 1995. Urban multiethnicity. Geographical Review 85 (4): 458-477.

Dixon, B.A. 2014. Learning to see food justice. Agriculture and Human Values 31 (2): 175-184.

DuPuis, E., D. Goodman, and J. Harrison. 2006. Just values or just value? Remaking the local in agro-food studies. In Between the local and the global: Confronting complexity in the contemporary agri-food sector, ed. T. Johnson and J. Murdoch, 241-268. Bingley: Emerald Group Publishing Limited.

Galli, A.M., and B.C. Clift. 2012. Food justice. In The Wiley-Blackwell encyclopedia of globalization, ed. G. Ritzer. Hoboken, NJ: Wiley.

Galt, R.E., L.C. Gray, and P. Hurley. 2014. Subversive and interstitial food spaces: Transforming selves, societies, and society-environment relations through urban agriculture and foraging. Local Environment. 19 (2): 133-146.

Gambirazzio, G.C. 2009. The Parallax view: race, land and the politics of place-making in Locke, California. Ph.D. Dissertation. Geography Graduate Group. Davis, CA: University of California, Davis.

Gilmore, R.W. 2017. Abolition geography and the problem of innocence. In Futures of Black radicalism, ed. G.T. Johnson and A. Lubin, 225-240. London: Verso Books.

Giménez, E.H., and A. Shattuck. 2011. Food crises, food regimes and food movements: Rumblings of reform or tides of transformation?". The Journal of Peasant Studies 38 (1): 109-144.

Gottlieb, R., and A. Joshi. 2010. Food justice. Cambridge MA: MIT Press.

Grey, S., and R. Patel. 2015. Food sovereignty as decolonization: Some contributions from indigenous movements to food system and development politics. Agriculture and Human Values 32 (3): 431-444.

Griswold del Castillo, R. 1998. Manifest destiny: The Mexican-American War and the Treaty of Guadalupe Hidalgo. Southwestern Journal of Law and Trade in the Americas 5: 31-43.

Guthman, J. 2011. If they only knew: The unbearable whiteness of alternative food. In Cultivating food justice: Race, class and sustainability, ed. A. Alkon and J. Agyeman, 263-281. Cambridge MA: MIT Press.

Hardesty, S., G. Feenstra, D. Visher, T. Lerman, D. Thilmany-McFadden, A. Bauman, T. Gillpatrick, and G.N. Rainbolt. 2014. Valuesbased supply chains: Supporting regional food and farms. Economic Development Quarterly 28 (1): 17-27.

Harris, C.I. 1993. Whiteness as property. Harvard Law Review 106 (8): 1707-1791.

Havens, E., and A. Roman-Alcalá. 2016. Land for food justice? AB 551 and structural change. Policy Brief 8. Land and Sovereignty. Oakland, CA: Food First/Institute for Food and Development Policy.

Heizer, R.F. 1993. The Destruction of California Indians: A collection of documents from the period 1847 to 1865 in which are described some of the things that happened to some of the Indians of California. Lincoln, NE: University of Nebraska Press.

Heizer, R.F., A.J. Almquist, and A.F. Almquist. 1977. The Other Californians: Prejudice and discrimination under Spain, Mexico, and the United States to 1920. Berkeley, CA: University of California Press.

Helzer, J.J. 1994. Continuity and change: Hmong settlement in California's Sacramento valley. Journal of Cultural Geography 14 (2): 51-64.

Hernandez, J. 2009. Redlining revisited: Mortgage lending patterns in Sacramento 1930-2004. International Journal of Urban and Regional Research 33 (2): 291-313.

Hernandez, J. 2014. Race, Market Constraints, and the Housing Crisis: A Problem of Embeddedness. Kalfou 1 (2): 29-58.

Ho, V. 2019. How an exodus of 'Bay Area refugees' is shaking up Sacramento. The Guardian, 2 July 2019, sec. Cities. https:// www.theguardian.com/cities/2019/jul/02/sacramento-california -bay-area-gentrification-rent.

Holmes, S. 2013. Fresh fruit, broken bodies: Migrant farmworkers in the United States, vol. 27. Berkeley, CA: University of California Press.

Hoover, B. 2013. White spaces in Black and Latino places: Urban agriculture and food sovereignty. Journal of Agriculture, Food Systems, and Community Development 3 (4): 109-115.

Hurtado, A.L. 1988. Indian survival on the California frontier, vol. 35. New Haven, CT: Yale University Press.

Johnson, G.T., and A. Lubin. 2017. Futures of Black radicalism. London, UK: Verso Books.

Leung, P.C.Y., and L.E.A. Ma. 1988. Chinese farming activities in the Sacramento-San Joaquin Delta: 1910-1941. Amerasia Journal 14 (2): 1-18.

London, J.K., K. Schwarz, M.L. Cadenasso, B.B. Cutts, C. Mason Jr., J. Lim, K. Valenzuela-Garcia, and H. Smith. 2018. Weaving community-university research and action partnerships for environmental justice. Action Research 16 (2): 173-189.

Martin, P. 2011a. California hired farm labor 1960-2010: Change and continuity. UC Davis Migration News and Rural Migration News.https://migrationfiles.ucdavis.edu/uploads/cf/files/2011may/martin-california-hiredfarm-labor.pdf.

Martin, P. 2011b. Labor relations in California agriculture: Review and outlook. ARE Update 15 (3): 5-8.

Martin, P., and J.E. Taylor. 1998. Poverty amid prosperity: Farm employment, immigration, and poverty in California. American Journal of Agricultural Economics 80 (5): 1008-1014.

McClintock, N. 2014. Radical, reformist, and garden-variety neoliberal: Coming to terms with urban agriculture's contradictions. Local Environment 19 (2): 147-171.

McClintock, N. 2018. Urban agriculture, racial capitalism, and resistance in the settler-colonial city. Geography Compass 12 (6): e12373.

McCutcheon, P. 2019. Fannie Lou Hamer's Freedom farms and Black agrarian geographies. Antipode 51 (1): 207-224. 
McKittrick, K. 2011. On plantations, prisons, and a Black sense of place. Social and Cultural Geography 12 (8): 947-963.

McKittrick, K. 2013. Plantation futures. Small Axe: A Caribbean Journal of Criticism 17 (3 (42)): 1-15.

McWilliams, C. 2000. Factories in the field: The story of migratory farm labor in California. Berkeley, CA: University of California Press.

Melamed, J. 2011. Represent and destroy: Rationalizing violence in the new racial capitalism. Minneapolis, MN: University of Minnesota Press.

Melamed, J. 2015. Racial capitalism. Critical Ethnic Studies 1 (1): $76-85$.

Meyers, G.P. 2015. Decolonizing a food system: Freedom farmers' market as a place for resistance and analysis. Journal of Agriculture, Food Systems, and Community Development 5 (4): 149-152.

Miles, M.B., and A.M. Huberman. 1994. Qualitative data analysis: An expanded sourcebook. Thousand Oaks, CA: Sage.

Minkoff-Zern, L. 2014. Knowing 'good food': Immigrant knowledge and the racial politics of farmworker food insecurity. Antipode 46 (5): 1190-1204.

Mitchell, D. 2010. Battle/fields: Braceros, agribusiness, and the violent reproduction of the California agricultural landscape during World War II. Journal of Historical Geography 36 (2): 143-156.

Napawan, N.C., and S.A. Townsend. 2016. The landscape of urban agriculture in California's capital. Landscape Research 41 (7): 780-794.

Omi, M., and H. Winant. 1994. Racial Formation in the US: From the 1960s to the 1990s. NewYork, NY: Routledge.

Passidomo, C. 2014. Whose right to (farm) the city? Race and food justice activism in post-Katrina New Orleans. Agriculture and Human Values 31 (3): 385-396.

Poppendieck, J. 1999. Sweet charity? Emergency food and the end of entitlement. New York, NY: Penguin.

Pudup, M.B. 2008. It takes a garden: Cultivating citizen-subjects in organized garden projects. Geoforum 39 (3): 1228-1240.

Pulido, L., and J. De Lara. 2018. Reimagining 'justice' in environmental justice: Radical ecologies, decolonial thought, and the Black radical tradition. Environment and Planning E: Nature and Space 1 (1-2): 76-98.

Qazi, J.A., and T.L. Selfa. 2005. The politics of building alternative agro-food networks in the belly of agro-industry. Food, Culture \& Society 8 (1): 45-72.

Ramirez, M.M. 2015. The elusive inclusive: Black food geographies and racialized food spaces. Antipode 47 (3): 748-769.

Reese, A.M. 2018. 'We will not perish; We're going to keep flourishing': Race, food access, and geographies of self-reliance. Antipode 50 (2): 407-424.

Reynolds, K. 2015. Disparity despite diversity: Social injustice in New York City's urban agriculture system. Antipode 47 (1): 240-259.

Robinson, C.J. 2000. Black Marxism: The making of the Black radical tradition. Chapel Hill: University of North Carolina Press.

Saxton, A. 1995. The Indispensable enemy: Labor and the anti-Chinese movement in California. Berkeley CA: University of California Press.

Sbicca, J. 2018. Food justice now! Deepening the roots of social struggle. Minneapolis, MN: University of Minnesota Press.

Sbicca, J., and J.S. Myers. 2017. Food justice racial projects: Fighting racial neoliberalism from the Bay to the Big Apple. Environmental Sociology 3 (1): 30-41.

Schwarz, K., R.V. Pouyat, and I. Yesilonis. 2016. Legacies of lead in charm city's soil: Lessons from the Baltimore ecosystem study. International Journal of Environmental Research and Public Health 13 (2): 209.

Slocum, R. 2006. Anti-racist practice and the work of community food organizations. Antipode 38 (2): 327-349.
Slocum, R. 2007. Whiteness, space and alternative food practice. Geoforum 38 (3): 520-533.

Sowerwine, J., C. Getz, and N. Peluso. 2015. The Myth of the protected worker: Southeast Asian micro-farmers in California agriculture. Agriculture and Human Values 32 (4): 579-595.

Tuck, E., and K.W. Yang. 2012. Decolonization is not a metaphor. Decolonization: Indigeneity, Education \& Society 1 (1): 1-40.

US Census Bureau. 2014. Race and Ethnicity; ACS 5-year estimates, Tables B01001 and B03002.

US Census Bureau. 2018a: Languages Spoken at Home ACS 2018, 1-Year Estimates Subject Tables. Table ID: S1601.

US Census Bureau 2018b. Race. ACS 2018, 5-Year Estimates (SE) Table: A03001. Race [8]. Generated by Social Explorer.

Vitiello, D., and L. Wolf-Powers. 2014. Growing food to grow cities? The potential of agriculture for economic and community development in the urban United States. Community Development Journal 49 (4): 508-523.

Walker, R. 2018. A Timeline of Stephon Clark's death at the hands of Sacramento police and the aftermath. The Undefeated, 23 March 2018. https://theundefeated.com/features/a-timeline-of-stephonclarks-death-at-the-hands-of-sacramento-police-to-the-protestat-the-kings-game/.

Welsh, E. 2002. Dealing with data: Using NVivo in the qualitative data analysis process. In Forum Qualitative Sozialforschung/Forum: Qualitative Social Research 3 (2), Art 26.

White, M.M. 2017. Freedom's seeds: Collective agency and community resilience: A Theoretical framework to understand agricultural resistance. Journal of Agriculture, Food Systems, and Community Development 7 (4): 17-21.

Wilson, F.J. 2010. Japanese American landownership during internment: A detailed examination of select regions of Sacramento and San Joaquin Counties. Master of Arts Thesis. Department of History. Sacramento, CA: California State University, Sacramento.

Yakini, M. 2013. Building a racially just food movement. Soul Fire Farm, 7 April 2013. https://www.soulfirefarm.org/2013/06/. Last accessed June 2019.

Yardi Matrix. 2020. Sacramento shows potential. Multifamily Report, Winter 2020. Yardi Matrix. https://matrix-multifamily-sacramento -report-winter-2020-1580863061.pdf. Last accessed 1 Aug 2020.

Publisher's Note Springer Nature remains neutral with regard to jurisdictional claims in published maps and institutional affiliations.

Jonathan K. London is an Associate Professor in the Department of Human Ecology at the University of California, Davis (UC Davis). He is also Faculty Director of the UC Davis Center for Regional Change, and Co-Director of the Community Engagement Core in the UC Davis Environmental Health Sciences Center. His research, teaching and engagement focus on environmental justice social movements and public policy, and employ a participatory action research approach.

Bethany B. Cutts is an Associate Professor of Human Dimensions of the Environment and Geospatial Analytics in the Department of Parks, Recreation, and Tourism Management and Faculty Fellow, Center for Geospatial Analytics at North Carolina State University. Her research focuses on participatory mapping, environmental justice, and geovisualization.

Kirsten Schwarz is an Associate Professor of Urban Planning and Environmental Health Sciences at the University of California, Los Angeles. She is an urban ecologist with research interests at the interface of environment, equity, and health. Her research focuses on environmental hazards and amenities in cities and how their distribution impacts minoritized communities. 
Li Schmidt has a M.S. in Community Development from UC Davis. She has worked in community-based food systems for over six years and her research and work center on equity, cultural foods, and health, including as a graduate student researcher with the University of California Sustainable Agriculture Research and Education Program.

Mary L. Cadenasso is a Professor of Plant Sciences at the University of California, Davis. She is an urban and landscape ecologist and her research explores how human action on the landscape, such as management and design, influences ecological processes. Current work focuses on the metropolitan regions of Baltimore and Sacramento and grasslands and high alpine of California. 